\title{
Studies on the components of the contact phase system in patients with acute nonlymphoblastic leukemia
}

Department of Clinical Medicine, Hematology Section, Medicine Faculty, UNICAMP, Cidade Universitária “Zeferino Vaz" - Campinas, Brazil

\begin{abstract}
The objective of the present study was to evaluate factors of the plasma kallikrein system in patients with acute nonlymphoblastic leukemia (ANLL), and compare the results to a normal control group. A prospective study was performed in the Tertiary Health Care Institution, Hemocentro, Campinas State University, Campinas, São Paulo, Brazil. Thirty-five patients, diagnosed as ANLL between 1988 and 1991, were considered for participation. Eleven patients were not elegible, according to the exclusion criteria: infection/ septicemia, previous treatment or blood transfusion. The study was performed with 24 ANLL patients, average age 34 years (16-69 years), 14 men and 10 women. Nineteen healthy volunteers, workers from the Hematology Center, average age 32 years (21-59 years), 11 men and 8 women, were the control group. Plasmatic prekallikrein, C1-inhibitor, alpha 2-macroglobulin, activated partial thromboplastin time, prothrombin time, factor XII, factor $\mathrm{XI}$, factor $\mathrm{V}$ and prealbumin were measured. Plasmatic prekallikrein ( $\mathrm{p}=0.02$ ) and prealbumin $(p=0.03$ ) were significantly decreased, and prothrombin time increased $(p=0.003)$ in the patient group when compared to the control. Significant correlation $(r=0.49$, critical value $=0.43, p<0.05)$ between prekallikrein and prealbumin, and between prothrombin time and factor $V(r=0.54$, critical value $=0.44, p<0.05)$ was demonstrated in the patient group. No correlation was found between parameters analysed and circulant blast count or leukemia subgroups. Statistical analysis was performed by the Wilcoxon test. Correlation between the parameters was also verified. These results suggest activation of the contact system or impaired liver synthesis in patients with ANLL, and could contribute to disease complications.
\end{abstract}

UNITERMS: Plasmatic prekallikrein. Contact phase. Nonlymphoblastic leukemia.

\section{INTRODUCTION}

$\mathrm{F}$ actor XII, plasmatic prekallikrein (PK) and HMWkininogen play an essential role in the initiation of important biological reactions, including intrinsic coagulation pathway. Recently, tecidual kallikrein and prekallikrein-kininogen complexes have been identified in neutrophils and myeloid precursors. ' Studies "in vitro" demonstrate that granulocytic elastase is capable of cleaving HMW-kininogen, PK and factors XII and XI. In addition, it can cleave $\mathrm{C} 1$-inhibitor to an inactive form. ${ }^{1}$

\section{Address for correspondence:}

Joyce M. Annichino-Bizzacchi,

Hemocentro/UNICAMP, CP 6198

Campinas/SP - Brasil - CEP 13081-970
Disturbances of hemostasis are still a major problem in patients with acute leukemia, and activation of the contact phase or proteolysis of contact system components, if present, could contribute to these alterations.

Although a relationship exists between leukocytes and the kallikrein-kinin system, there are few clinical studies on leukemia patients.

Chiba et al (1979) studied 14 acute myelocytic leukemia patients. Before and during the treatment they found decreased plasmatic PK and normal C1-INH.

Buzerak et al (1982) studied 39 patients with acute leukemia and described increased kallikrein-kinin system activation in patients with a higher blast count.

This study was undertaken to evaluate some contact system parameters in 24 patients with ANLL at diagnosis, compared to a control group, and to verify correlation between possible alterations and blast count, some coagulation parameters and prealbumin. 


\section{PATIENTS AND METHODS}

Blood samples were collected by clean venipuncture, in plastic tubes containing sodium citrate $3,8 \%$, in a 9:1 proportion. Following its centrifugation, the obtained plasma was kept at $-80^{\circ} \mathrm{C}$ until its use.

A prospective study, including all new cases diagnosed as ANLL in the Hemocentro at Unicamp between 1988 to 1991, was developed. Thirty-five cases of ANLL were considered for participation in this study. Eleven patients were not elegible, according to the exclusion criteria: infection/septicemia, previous treatment or blood transfusion. Infection/septicemia was ruled out in the absence of fever, negative blood and urine culture, normal thorax X-ray and stable blood pressure. Finally, blood was analysed from 24 ANLL patients, average age 34 years (1669 years), 14 men and 10 women. Diagnosis of renewed ANLL was based on blood count, bone marrow biopsy, cytology and cytochemistry. They were classified according to the FAB-system ${ }^{4}$ (six M1, nine M2, one M3, two M4, two M5, two M6 and two M7 cases). Clinical bleeding was present in 5 patients ( $21 \%$ of cases) and characterized by epistaxis (cases 4 and 13), ecchymosis (cases 7 and 16) and hematuria (case 23). Clinical thrombosis was not present. Nineteen healthy volunteers, workers from the Hemocentro at Unicamp, average age 32 years (21-59 years), 11 men and 8 women, were the control group.

Plasmatic PK was measured after dextran sulphate activation, using an amidolytic assay ${ }^{5}$ with Ac-Phe-Arg-pNA chromogenic substrate. "Kallikreinlike" activity was evaluated in the same way as the prekallikrein assay, substituting dextran sulphate as buffer.

C1-inhibitor (C1-INH), alpha 2-macroglobulin (A2) and prealbumin (PA) were measured by rocket immunoelectrophoresis. ${ }^{7}$ Activated partial thromboplastin time (APTT) was measured with kaolin and rabbit brain cephalin. ${ }^{8}$ Prothrombin time (PT) was obtained with rabbit brain thromboplastin. ${ }^{9}$ The APTT and PT results were expressed as a ratio between coagulation time of patient plasma and a pool of 20 normal plasmas. Normal and prolonged APTT and PT reference plasmas were run daily as a laboratory quality control. Factor XI and factor XII were measured by APTT corrrection time, using deficient plasma in factor XI and XII (Stago diagnosis) respectively. ${ }^{10}$ Factor $\mathrm{V}$ was measured by a described procedure."

Platelet count was determined automatically (Cell dyn 1600, Unipath, California, USA).

Statistical analysis was carried out using the Wilcoxon test. Patients and controls were compared to all parameters studied. Patients were also separated according to leukemia subtypes, into group 1 (M1- 6 cases), group 2 (M2- 9 cases) and group 3 (M3 to M7- 8 cases). This last group was made up from 4 subgroups, to achieve a great number of patients, making statistical analysis possible. Correlation between various parameters was performed: blast count or leucocyte count and PK; C1-INH or A2; PA and PK, PT or factor V; and PK and PT or factor V. The difference at $\mathrm{p}<0.05$ was considered significant.

\section{RESULTS}

Table 1 summarizes peripheral blood count found in ANLL patients.

Table 1

Blood count of ANLL patients

\begin{tabular}{|c|c|c|c|c|c|}
\hline & & $\begin{array}{l}\text { hemoglobin } \\
\mathrm{g} / \mathrm{dl}\end{array}$ & $\begin{array}{c}\text { leucocytes } \\
/ \mathrm{mm}^{3}\end{array}$ & $\begin{array}{l}\text { blasts } \\
/ \mathrm{mm}^{3}\end{array}$ & $\begin{array}{c}\text { platelets } \\
/ \mathrm{mm}^{3}\end{array}$ \\
\hline & 1.M1 & 8,1 & 3000 & 1500 & 62000 \\
\hline L & 2.M1 & 10,0 & 3400 & 1600 & 55000 \\
\hline$E$ & 3.M1 & 7,5 & 1100 & 500 & 47000 \\
\hline$U$ & 4.M1 & 5,1 & 5100 & 1800 & 20000 \\
\hline $\mathrm{K}$ & 5.M1 & 9,3 & 130000 & 111000 & 84000 \\
\hline$E$ & $6 . \mathrm{M} 1$ & 7,3 & 26000 & 18000 & 35000 \\
\hline$M$ & 7.M2 & 7,5 & 1500 & 900 & 15000 \\
\hline 1 & 8.M2 & 7,6 & 2500 & 1900 & 21000 \\
\hline A & 9.M2 & 8,8 & 6000 & 4000 & 90000 \\
\hline & 10.M2 & 7,5 & 11400 & 8700 & 102000 \\
\hline & 11.M2 & 6,8 & 2100 & 1100 & 176000 \\
\hline$S$ & 12.M2 & 4,3 & 145000 & 110000 & 55000 \\
\hline$U$ & 13.M2 & 8,8 & 3500 & 1200 & 12000 \\
\hline B & 14.M2 & 8,2 & 188000 & 165000 & 75000 \\
\hline G & 15.M2 & 11,5 & 50000 & 38000 & 68000 \\
\hline $\mathrm{R}$ & 16.M3 & 8,4 & 3500 & 2000 & 2000 \\
\hline $\begin{array}{l}O \\
U\end{array}$ & $\begin{array}{l}17 . \mathrm{M} 4 \\
18 . \mathrm{M} 4\end{array}$ & $\begin{array}{r}9,4 \\
10,7\end{array}$ & $\begin{array}{r}1900 \\
22200\end{array}$ & $\begin{array}{r}1100 \\
12000\end{array}$ & $\begin{array}{l}25000 \\
59000\end{array}$ \\
\hline$P$ & 19.M5 & 8,0 & 20000 & 15000 & 10000 \\
\hline$S$ & 20.M5 & 7,0 & 30000 & 18000 & 42000 \\
\hline & 21.M6 & 10,0 & 1200 & 800 & 40000 \\
\hline & 22.M6 & 6,1 & 157000 & 137000 & 35000 \\
\hline & $\begin{array}{l}23 . M 7 \\
24 . M 7\end{array}$ & $\begin{array}{l}5,0 \\
6,3\end{array}$ & $\begin{array}{r}73000 \\
4000\end{array}$ & $\begin{array}{r}56000 \\
1800\end{array}$ & $\begin{array}{l}36000 \\
10000\end{array}$ \\
\hline & verage & 7.8 & $35-56$ & 29070 & 49000 \\
\hline
\end{tabular}


The results (tables 2 and 3) demonstrated that APTT, $\mathrm{C} 1-\mathrm{INH}, \mathrm{A} 2$, factor XI, factor XII and factor V were not different between patients and the control group. Kallikreinlike activity was not increased in patients. PK was decreased $(\mathrm{p}=0.02)$ and PT increased $(\mathrm{p}=0.003)$ in ANLL patients when compared to the control. PA was significantly lower $(p=0.03)$ in the patient group than in the control one. When patients were separated into subgroups according to FABclassification, no difference was verified in any variable measured. There was no correlation between circulant blast count or leucocyte count and PK, A2 or C1-INH. A positive correlation between $\mathrm{PK}$ and $\mathrm{PA}(\mathrm{r}=0.49$, critical value $=$ $0.43, \mathrm{p}<0.05)$, and between PT and factor V $(\mathrm{r}=0.54$, critical value $=0.44, p<0.05$ ), was observed.

\section{DISCUSSION}

Disturbances of hemostasis are still a frequent problem in patients with acute leukemia. Prekallikrein or factor XII deficiency are associated with an in vitro coagulopathy (prolonged APTT), in the absence of clinical bleeding. However, if activation of the contact system or proteolysis of the components of this system is present in leukemia, intrinsic blood coagulation pathway could be compromised, contributing to the coagulopathy seen in these patients.

The objective of this study was to evaluate some components of the contact system in 24 ANLL patients. Patients were studied at diagnosis, without chemotherapy or infection, to avoid conditions which could, per se, alter the contact system.

Table 2

Parameters of the contact system, coagulation and PA in ANLL

(R) Ratio of time of coagulation in seconds of patient to a pool of normal plasma.

\begin{tabular}{|c|c|c|c|c|c|c|c|c|c|c|}
\hline & & $\begin{array}{r}\text { APTT } \\
(\mathrm{R})\end{array}$ & $\begin{array}{r}\mathrm{PK} \\
(\mathrm{U} / \mathrm{ml})\end{array}$ & $\begin{array}{l}\text { C1 } \\
(\%)\end{array}$ & $\begin{array}{l}\text { A2 } \\
(\%)\end{array}$ & $\begin{array}{r}X I \\
(\%)\end{array}$ & $\begin{array}{l}\text { XII } \\
(\%)\end{array}$ & $\begin{array}{r}\text { PA } \\
(\%)\end{array}$ & $\begin{array}{r}\text { PT } \\
\text { R } \\
\end{array}$ & $\begin{array}{l}\text { F V } \\
(\%)\end{array}$ \\
\hline & 1.M1 & 1.35 & 0.26 & 78 & 82 & 120 & 69 & 47 & 1.2 & 70 \\
\hline L & 2.M1 & 1.18 & 0.61 & 86 & 107 & 120 & 160 & 68 & 1.1 & 70 \\
\hline$E$ & 3.M1 & 1.02 & 0.17 & 89 & 93 & 63 & 77 & 42 & 1.3 & 100 \\
\hline U & 4.M1 & 0.94 & 0.31 & 71 & 106 & 73 & 119 & 50 & 1.4 & 120 \\
\hline $\mathrm{K}$ & 5.M1 & 0.96 & 0.23 & 86 & 81 & 121 & 69 & - & 1.0 & 80 \\
\hline $\mathrm{E}$ & $6 . \mathrm{M1}$ & 1.00 & 0.41 & 106 & 108 & 99 & 133 & 81 & 1.0 & - \\
\hline M & 7.M2 & 0.95 & 0.40 & 100 & 100 & 112 & 160 & 100 & 1.1 & 72 \\
\hline 1 & 8.M2 & 1.02 & 0.41 & 94 & 108 & 103 & 153 & 56 & 1.0 & 62 \\
\hline \multirow[t]{3}{*}{ A } & $9 . \mathrm{M} 2$ & 0.90 & 0.41 & 79 & 96 & 101 & 86 & 50 & 1.4 & 120 \\
\hline & 10.M2 & 1.02 & 0.62 & 92 & 75 & 108 & 66 & 50 & 1.2 & 105 \\
\hline & 11.M2 & 1.03 & 0.35 & 92 & 67 & 103 & 153 & 40 & 1.1 & 54 \\
\hline S & 12.M2 & 0.95 & 0.43 & 87 & 129 & 74 & 109 & 40 & 1.4 & 56 \\
\hline U & 13.M2 & 0.88 & 0.76 & 87 & 92 & 175 & 118 & 100 & 1.5 & 100 \\
\hline B & 14.M2 & 0.77 & 0.36 & 95 & 75 & 48 & 128 & 70 & 1.2 & 92 \\
\hline G & 15.M2 & 1.22 & 0.12 & 90 & 167 & 65 & 44 & - & 1.2 & 56 \\
\hline$R$ & 16.M3 & 1.20 & 0.57 & 100 & 142 & 40 & 34 & 73 & 1.2 & 110 \\
\hline 0 & 17.M4 & 1.14 & 0.29 & 70 & 150 & 58 & 71 & 46 & 1.5 & 35 \\
\hline U & 18.M4 & 1.02 & 0.60 & 75 & 87 & 119 & 109 & 200 & 1.2 & 140 \\
\hline$P$ & 19.M5 & 1.35 & 0.19 & 90 & 118 & 66 & 66 & 80 & - & 120 \\
\hline \multirow[t]{7}{*}{ S } & 20.M5 & 1.04 & 0.20 & 90 & 157 & 100 & 190 & 43 & 1.3 & 60 \\
\hline & 21.M6 & 0.76 & 0.62 & 81 & 108 & 139 & 171 & 87 & 1.2 & 120 \\
\hline & 22.M6 & 1.17 & 0.46 & 100 & 154 & 58 & 94 & - & 1.3 & 82 \\
\hline & 23.M7 & 1.52 & 0.53 & 93 & 86 & 160 & 120 & 67 & 1.1 & 105 \\
\hline & 24.M7 & 1.24 & 0.67 & 70 & 175 & 175 & 135 & 100 & 1.2 & 100 \\
\hline & average & 1.07 & 0.41 & 87 & 110 & 100 & 109 & 70 & 1.22 & 87 \\
\hline & SD & 0.18 & 0.17 & 9 & 31 & 37 & 42 & 36 & 0.15 & 27 \\
\hline
\end{tabular}




\section{Table 3}

Parameters of the contact system and coagulation in ANLL and control group

(R) Ratio of coagulation time in seconds of patient to a pool of normal plasmas.

\begin{tabular}{lrrr}
\hline & & Patient & Control \\
\hline APTT & R & 1.0 & 1.06 \\
PK & $(\mathrm{U} / \mathrm{ml})$ & 0.41 & $0.52^{\star}$ \\
C1 & $(\%)$ & 87 & 93 \\
A2 & $(\%)$ & 110 & 109 \\
XI & $(\%)$ & 100 & 101 \\
XII & $(\%)$ & 109 & 100 \\
PT & $R$ & 1.22 & $1.10^{* \star}$ \\
V & $(\%)$ & 92 & 87 \\
PA & $(\%)$ & 70 & $111^{\star * *}$ \\
\hline${ }^{p}=0.02$ & & & \\
$* p=0.003$ & & & \\
$\cdots p=0.03$ & & &
\end{tabular}

Bleeding was present in $21 \%$ of cases, a little less than that described by others, and thrombocytopenia was probably the major responsible factor. The exclusion of patients with infection/septicemia, a condition that increases the risk of bleeding in patients with thrombocytopenia, could explain the lower incidence of hemorrhagia in our patients.

We have demonstrated that ANLL patients have low biologic PK activity. This fact could suggest an activation of the contact phase, as described in previous reports. ${ }^{2,3}$

Otherwise, the lack of reduction of the main PK inhibitor, could disprove that the kallikrein-kinin system has been activated in leukemia patients. Studies demonstrated increased synthesis of C1-INH in inflammatory processes, mediated by interleucin- 6 , inferring that it could be an acute phase protein. ${ }^{12-13}$ The normal level of C1-INH in our patients does not rule out increased turnover, since synthesis could be increased, associated with simultaneous consumption, by kallikreinkinin system activation. C1-INH antigen frequently is not reduced even after consumption of the inhibitor by an active enzyme; the antigen may even appear increased in Laurell assay, due to faster electrophoretic mobility of the enzyme-inhibitor complex. Indeed, the immunologic method employed for C1-INH measurement can reveal levels of inactive inhibitors. ${ }^{6,14-15}$

Kallikrein is present in leucocytes and myeloid precursors. So, in leukemia, a disease with an increased number of these cells, we could expected a correlation between blast cell count and PK, $\mathrm{C} 1$ or $\mathrm{A} 2$ levels. However, our results did not confirm this hypothesis.

Kallikrein-like activity was not increased in our patients, suggesting there was no spontaneous proteolysis triggered by enzymes liberated from blasts cells.

PK is synthetized in liver, and it can be a reliable index of liver function. ${ }^{16}$ Impaired liver function could contribute to the decreased PK level in our patients. The finding of decreased PA, a sensitive parameter of liver synthesis, and a significative correlation between PK and PA in our ANLL patients, corroborate this hipothesis. However, we have to take into account that prealbumin can be decreased in clinical situations without liver synthesis insufficiency, in which a modulation of protein synthesis occurs, with an increase in acute phase proteins and reduction in others. The great majority of these alterations are mediated by cytokines that act on hepatocytes. ${ }^{17}$ The evaluation of other proteins that are involved in acute phase response, like fibrinogen, reactive protein $\mathrm{C}$ and alpha 1-antitripsin, would be an important aid in the analysis of our results.

Previous studies described coagulation abnormalities in myelocytic leukemia, particularly in the subtype M3. Blast cells are rich in procoagulants which can trigger blood coagulation by direct factor $\mathrm{X}$ activation, or by tissue factor-like activity. In some patients the activation of blood coagulation can determine an increase of APTT, PT and thrombin time. Activation markers of blood coagulation, like thrombin-antithrombin complexes, fibrinogen degradation products and Ddimmers, are of interest in confirming this activation or not. In our patients, PT and PTTA were measured and PT was the only parameter altered.

PT increases by reduction of factor II, VII, X or fibrinogen. So, impaired liver synthesis, vitamin K deficiency, isolated reduction of one of these factors, or increased consumption, could raise PT.

Therefore, impairment of liver synthesis could contribute to the increased PT verified in our patients, favored by simultaneous PK and PA decrease. An increased turnover, due to activation of blood coagulation could also have contributed to this finding.

There was no correlation between PK and PT, suggesting the kallikrein-kinin system does not play an important role in this alteration.

In some patients (cases 1,15 and 19) activation of the blood coagulation intrinsic pathway by kallikrein is suggested by simultaneous PK and factor XII decrease.

Further investigations are needed to clarify the contact system in ANLL. Determination of kallikrein-C1INH complexes or activity and antigen levels of PK and C1-INH should be employed to elucidate these points. 


\section{RESUMO}

Objetivo: Este estudo teve por objetivo avaliar alguns componentes do sistema calicreína-cininas em pacientes com leucemia aguda não linfoblástica (LANL) e compará-los a um grupo controle normal. Desenho e local: Um estudo prospectivo foi realizado no Hemocentro de Campinas, São Paulo, uma Instituição de atendimento em hematologia, de nível terciário.

Participantes: Inicialmente 35 pacientes diagnosticados como LANL, entre 1988 1991, foram considerados para participar do estudo. Onze pacientes foram excluidos de acordo com os critérios de exclusão: presença de infecção/septicemia, transfusão sanguínea ou quimioterapia prévia. Ao final foram analisados 24 pacientes portadores de LANL, e comparados a um grupo controle normal. Métodos: Os parâmetros analisados foram a procalicreína plasmática, o C1-inibidor, a alfa 2-macroglobulina, o tempo de tromboplastina parcial ativado, o tempo de protrombina, o fator XII, o fator XI, o fator V e a pré-albumina.

Mensuração: $\mathrm{A}$ análise estatística foi realizada através do teste de Wilcoxon. Também verificou-se a presença de correlação entre vários parâmetros analisados. Resultados: Os níveis de procalicreína plasmática $(p=0.02)$ e de pré-albumina ( $p=0.03)$ estavam significativamente diminuídos e o tempo de protrombina significativamente prolongado $(\mathrm{p}=0.003)$ no grupo de pacientes, quando comparados ao grupo controle. No grupo de pacientes observou-se uma correlação positiva entre a procalicreína e a pré-albumina plasmática $(r=0.49$, valor crítico $=0.43, p<0.05)$, e entre o tempo de protrombina e o fator $V(r=0.54$, valopr crítico $=0.44$, $\mathrm{p}<0.05)$. Não houve correlação entre os parâmetros avaliados e o número de células blásticas circulantes ou o subtipo de leucemia. Conclusões: Esses resultados sugerem uma ativação da fase de contato e/ou comprometimento da função de sintese proteica hepática em pacientes portadores de LANL, podendo contribuir para as complicações dessa patologia.

\section{REFERENCES}

1. Bhoola KD, Figueroa C. KininBioregulation. Pharmacol Rev 1992; 44:1-80.

2. Chiba Y, Ishihara H, Haned Y, Yoshida Y. Kallikrein system during treatment of hematological malignancies. Adv Exp Med Biol 1979;120A:501-9.

3. Buzherak NF. Dynamics changes of the kinin system of the blood plasma in patients with acute leucosis. Urach Delo 1982;9:80-83.

4. Bennett JM, Catovsky D, Daniel MT, Flandrin G, Galton DAG, Gralnik HR, Sultan C.Proposals for classification of the acute leukemias: French American British (FAB) Cooperative Group. Br J Haematol 1978;33:451-58.

5. Oliva MLV, Grisolia D, Sampaio MV, Sampaio CAM. Properties of a highly purified human plasma kallikrein. Agents Actions 1982;9:52-55.

6. Juliano MA, Juliano L.. Synthesis and kinetic parameters of hydrolysis by trypsis of some acyl-arginyl-p-nitroanilides and peptides containing arginyl-p-nitroanilide. Brazilian J Med Biol Res 1985;18:435-445.

7. Laurell CB. Quantitative estimation of proteins by electrophoresis in agarose gel containing antibodies. Anal Biochem 1966;15:45-52.
8. Proctor PR, Rappaport SI. The partial thromboplastin time with kaolin. Am J Clin Pathol 1961;36:212-19.

9. Quick AJ. The prothrombin in haemophilia and obstructive jaundice. J Biol Chem 1935;109:73.

10. Laurieu MJ, Weillard C. Utilization de la cephaline dans le test de coagulation. Rev d'Hematol 1957;12: 199-210.

11. Quick AJ. The assay and properties of labile factor V. J Clin Pathol 1960;13:457.

12. Donaldson VH. Serum inhibitor of C1- esterase in health and disease. J Lab Clin Med 1966;68:369-382.

13. Zuraw BL, Lotz M. Regulation of the hepatic synthesis of $\mathrm{C} 1$ inhibitor by the hepatocyte stimulating factors interleukin 6 and interferon gamma. J Biol Chem 1990;265:12664-12670.

14. Gallimore MJ. Discrepancies between antigen concentrations and functional activities of plasma protease inhibitors. In: Peeters $\mathrm{H}$, eds. Protides of Biological Fluids.London Pergamon Press, 1980.

15. Keelen AA, Meyer KC, Vogt JM, Edson JR. Kallikrein inhibition and $\mathrm{Cl}$-esterase inhibitor levels in patients with the lupus inhibitor. Am J Clin Pathol 1987;88:223-228.

16. Cordova C, Violi F, Alessandri C, Ferro D, Saliola M, Musca A, Balsano F. Prekallikrein and factor VII as prognostic indexes of liver failure. Am J Clin Pathol 1979; 19:579-582.

17. Abbas AK, Lichtman AH, Pober JS. Cellular and molecular immunology. in: WB Saunders, eds., 1991, chapter 11, 226-243. 